\title{
Drivers and implications of medical tourism: a neo-institutional perspective ${ }^{1}$
}

\author{
Rossella Canestrino - Pierpaolo Magliocca - Claudio Nigro
}

\begin{abstract}
Purpose of the paper: The paper aims at adding a new contribution to the field of Medical Tourism by proposing a Situationist View of the phenomenon. In doing this, we have taken into account the global dimension of Medical Tourism, thus widening the well-known neo-institutional framework.

Methods: We scanned Business Source Premier, Elsevier Freedom Collection, and JSTOR, using "Medical Tourism and neo-institutionalism" search criteria. After realizing the lack of resources about the topic, we matched the available contributions about Medical Tourism and neo - institutionalism in order to develop a new theoretical framework.

Findings: The original neo-institutional model has been widened for the first time in order to provide a better understanding of Medical Tourism's worldwide dimension.

Originality and limits of the study: The main contribution of the paper is its potential to reach beyond the more narrowly focused journals where many of the contributions about Medical Tourism reside.

The lack of empirical evidence is one of the main limits of the paper. Because of the innovativeness of the developed theoretical framework, future investigations need to be carried out.

Practical Implications: The developed theoretical framework provides the basis for a better understanding of Medical Tourism at a global level, as well as of the dynamics that underlie it. Additionally, our paper poses new and interesting research questions about the potential sustainability of Medical Tourism at a societal level, thus requiring future investigation into the issue.
\end{abstract}

Key words: medical tourism; neo-institutionalism symbolic institutional framework; normative institutional framework

\section{Introduction}

Medical or health tourism has increased greatly in recent years, since a large number of patients from all over the world have travelled to other host countries in order to receive medical care.

Even if travel for medical care (and wellbeing) has long existed, some differences are soon emerging and a form of "reverse globalization" is still

1 The paper has been developed thanks to the Funds for a Research Project of the University of Foggia in 2014. It is the result of the joint collaboration of the three authors (cited in alphabetic order). In fact, Canestrino Rossella is responsible for sections 1, 4 and 7; Magliocca Pierpaolo is responsible for sections 2, 3 and 5; Nigro Claudio is responsible for section 6 . 
Sinergie Vol. 33, N. 97, 2015

arising: patients from more developed countries move to less developed and emerging countries driven by a combination of costs, access to services and quality of the health care (Connell, 2013). Thailand, Singapore and Malaysia, but also India, are capitalizing their reputations as the most important medical tourism destinations in the world by combining high quality medical services at competitive prices with tourist packages. Thailand is, for example, the preferred destination for cosmetic surgery and sex change operations, while Singapore attracts patients who need neurological surgery and stem cell therapy (Pocock and Phua, 2011).

But why do people travel to less developed countries in order to receive medical care?

Generally speaking, patients travel to another country to receive more affordable care, or care that is more accessible than in their home country; in particular, cross-border health care is motivated by lower costs, avoidance of long waiting times, or services that are not available in one's own countries (Hopkins et al., 2010).

Not surprisingly, Thailand, Singapore, Malaysia, India and East Asia are the preferred destinations by US patients. The latter ones are mainly driven by the rise of health costs in the US, but also by the significant reduction in the percentage of US residents with healthcare insurance.

In many less developed and emerging countries the healthcare industry is dominated by the private sector. Private profits - mainly deriving from fees paid by foreign patients - are often replaced offshore to companies located in different countries in order to be invested in private hospital chains. Thus a "double healthcare system" develops: one, private, high quality system, limited to foreign or rich patients; and another, public, low quality one, addressed to national citizens who are unable to pay (Pocock and Phua, 2011).

But that's not all.

Medical Tourism may foster economic development in host countries, encouraging foreign direct investments in both health and tourism infrastructures. This would explain why governments in Indonesia and Vietnam have expressed their interest in supporting the industry (Blouin et al., 2009).

In spite of this, Medical Tourism poses a wide academic debate about the differences, in both normative and moral rules, that actually exist at an international level.

The lack of homogeneity among national rules impels patients to look abroad to undergo "extreme" procedures, e.g. stem cell therapy, surrogacy and even euthanasia, which are not undertaken in their home countries (Higginbotham, 2011; Inhorn, 2011). In addition, what is considered a-moral (or not allowed) at "home" becomes moral in the host country, thus posing important ethical concerns (Canestrino, 2007), that suggest future exploration.

Depending on these considerations, our paper aims at analyzing both the drivers and the implications of Medical Tourism by adopting a Situatonist View (Mastroberardino and Nigro, 2009; Calabrese et al. 2011). In doing this, we provide a neo-institutional interpretation of the phenomenon at a worldwide level for the first time. 
Our paper is a theoretical one: sections 2, 3 and 4 point out the literature review about Medical Tourism, examining the reasons why people travel to access to cross-border health care. Section 5 and 6 provide new insights by exploring Medical Tourism within the Neo-Institutional Framework. Discussions and conclusions are shown in section 7. Within this final section, suggestions for further research are also provided.

\section{Cross-border health care: the conceptualization of Medical Tourism}

Definitions of Medical Tourism shape an undifferentiated box inside which the terms "Medical Tourism", "Health Tourism", or "Medical Travel" involve many aspects of a more complicated, and often little understood, phenomenon, like invasive procedures, medical check-ups, dental tourism, wellness tourism, and "diasporic tourism", as well as maternity or even death tourism (Connell, 2013).

As a consequence, the drivers that underlie the phenomenon are frequently underestimated.

This is the reason why the more minimalist definitions of Medical Tourism need to be specified.

Some authors often refer to Medical Tourism as a form of "travel" undertaken by citizens to obtain medical care (Cormany and Baloglu, 2011) without any reference to the type of procedures the patients expect to undergo. But the interventions range from yoga and massages, cosmetic surgeries, and dentistry, to operations like hip replacements and transplants, reproductive procedures and even "death tourism".

Not surprisingly, Wellness Tourism is generally the subject of a distinct literature (Smith and Puczko, 2009); Dental Tourism has also sometimes been excluded from definitions of Medical Tourism (Pollard, 2011; Turner, 2008).

Depending on the above considerations, Medical Tourism is distinct from Health Tourism (Lunt and Carrera, 2010; Lunt et al., 2012), because the latter is mainly devoted to low-key, therapeutic and non-invasive procedures such as check-ups, water-care and dentistry (e.g.: Wellness Tourism) (Connell, 2013).

Some authors neglect the leisure aspect of Medical Tourism, while many others emphasize the deep linkage between the health and tourism industries under the pressure of Medical Tourism.

According to Kopson (2010, p. 1) Medical Tourism consists in "travel[ing] to another country to receive medical, dental and surgical care while at the same time receiving equal to or greater care than they would have in their own country... because of affordability, better access to care or a higher level of quality of care". For Cormany and Baloglu (2011), Medical Tourism refers to "the act of travelling abroad to obtain medical care". Similarly, Adams et al. (2013) refer to the phenomenon as the practice of patients to travel out of the country with the intention of receiving medical care. The authors also focus on the distinction between public and private health care since medical tourists are patients who pay for medical care "out of pocket".

Johnston et al. (2010) emphasize "patients' intentions" to access medical care and often surgery procedures by leaving their country of residence, 
sinergie Vol. 33, N. 97, 2015

while Connell (2006) highlights the linkage between patients' travel for care and their expectations concerning substantial and long-term outcomes.

The concept of "Tourism" has been largely neglected by the authors of the above contributions. But without ignoring the pain and desperation that are implicit in some medical procedures, and that often led patients to go abroad, connotations of pleasure, relax, and education also belong to the Medical Tourism Literature.

Laws (1996) defined Medical Tourism as travelling from home to other destinations to improve one's health condition as well as one's type of leisure. Connell (2006) described Medical Tourism as popular practice of mass culture according to which people look for cross-border medical care taking the opportunity to visit the host country and enjoy local touristic attractions.

Similarly, Jagyasi (2008, p. 10) refers to Medical Tourism as "the set of activities in which a person travels often long distance or across the border, to avail medical services with direct or indirect engagement in leisure, business or other purposes". The underlined perspectives include: "a vacation that involves travelling across international borders to obtain a broad range of medical services. It usually includes leisure, fun and relaxation activities, as well as wellness and health-care service" (Heung et al., 2010, p. 236).

Generally speaking, health tourists take the opportunity to visit a popular travel destination, thus combining health care with a vacation.

The factors driving Medical Tourism and its worldwide growth will be examined in the following section.

\section{Why do people travel for medical care?}

From a general perspective, Medical Tourism may be broken down into two main categories: a) Outbound Medical Tourism (When patients travel away from their home country); and b) Inbound Medical Tourism (When foreign patients go to a given country to receive medical care e.g.: India, Malaysia, or Singapore $)^{2}$. For our purpose, we only investigate outbound Medical Tourism and the reason why people go abroad for medical care. these:

Many factors drive the actual growth of Medical Tourism. Among

1) The rapid rise of healthcare costs in many developed countries and the substantially lower costs of healthcare abroad (e.g.: Thailand, Malaysia and Singapore, but also Hungary, Poland, Turkey and Mediterranean countries) (Pocock and Phua, 2011; Kopson, 2010);

2) The long waiting times in many developed countries and the speed of obtaining treatments abroad (Lunt and Carrera, 2010; Hadi, 2009); and

3) The presence of legal, or moral restrictions that impel patients to go abroad for treatment that is not available at home (Connell, 2013).

2 Kopson (2010) referred to three main categories: a) Travel away from the U.S (Outbound); b) Travel to the U.S. (Inbound); and c) Travel between two nonU.S. countries (non-U.S.). 
By analyzing the U.S. market, Kopson (2010) included, among the most common driving factors of Medical Tourism growth, the significant reduction in the percentage of U.S. residents with healthcare insurance. Similarly, the tightening of entry requirements in the U.S. (and in many other western Rossella Canestrino Pierpaolo Magliocca Claudio Nigro Drivers and implications of medical tourism: a neo-institutional countries) after the attack on the World Trade Center on September $11^{\text {th }}$ 2001, diverted a large share of patients from the U.S. to other destinations like Jordan or Cuba (Hadi, 2009).

But the leading driving force of outbound Medical Tourism is the difference in costs for various treatment' options between developed and emerging countries.

Table 1 shows the comparative costs of different medical procedures. We used the data provided by allmedicaltourism.com, as well as by healthtourism.com, treatmentabroad.com and the Italian Portal for Medical tourism, in order to compare the prices for the same procedures in both the U.S. and the most important emerging destinations for Medical Tourism.

For an aortic or heart bypass, U.S. patients may save up to $85 \%$ on medical costs by going to India, and up to $92 \%$ for a total disc replacement in Malaysia.

The increased ease and reduced costs of international travel, the development of medical tourism facilitators (e.g.: destination managers, brokers, and insurance agencies), as well as the possibility to combine tourist attractions with medical procedures, have led a growing number of U.S. patients to go abroad for medical care.

Tab. 1: Comparative costs of selected medical procedures in India, Thailand, Singapore, Malaysia

\begin{tabular}{|c|c|c|c|c|c|c|}
\hline $\begin{array}{l}\text { Procedure } \\
\text { Type }\end{array}$ & Procedure & $\begin{array}{l}\text { US (Average } \\
\text { price } \$)^{*}\end{array}$ & $\begin{array}{l}\text { India } \\
\text { (U.S. \$) }\end{array}$ & $\begin{array}{l}\text { Thailand } \\
\text { (U.S. \$) }\end{array}$ & $\begin{array}{l}\text { Singapore } \\
\text { (U.S. \$) }\end{array}$ & $\begin{array}{l}\text { Malaysia } \\
\text { (U.S. \$) }\end{array}$ \\
\hline \multirow[t]{3}{*}{ Heart Surgery } & $\begin{array}{l}\text { Heart bypass } \\
\text { (CABG) }\end{array}$ & 52,450 & $\begin{array}{c}7,500- \\
8,500\end{array}$ & 18,700 & $\begin{array}{c}16,400- \\
16,500\end{array}$ & $\begin{array}{c}12,100- \\
19,400\end{array}$ \\
\hline & $\begin{array}{l}\text { Heart valve } \\
\text { replacement }\end{array}$ & 60,000 & $\begin{array}{l}9,500- \\
10,000\end{array}$ & 13,900 & 12,300 & 9,200 \\
\hline & Angioplasty & 23,930 & 3,300 & $\begin{array}{c}10,000- \\
20,000\end{array}$ & $\begin{array}{l}9,700- \\
14,000\end{array}$ & $\begin{array}{l}4,900- \\
10,700\end{array}$ \\
\hline \multirow[t]{3}{*}{ Orthopedic } & $\begin{array}{l}\text { Hip } \\
\text { Replacement }\end{array}$ & 25,000 & 5,000 & $\begin{array}{l}7,500- \\
17,500\end{array}$ & $\begin{array}{l}9,200- \\
21,000\end{array}$ & $\begin{array}{l}5,800- \\
10,000\end{array}$ \\
\hline & $\begin{array}{l}\text { Hip } \\
\text { Resurfacing }\end{array}$ & 49,830 & 5,000 & $\begin{array}{c}10,000- \\
17,000\end{array}$ & $\begin{array}{c}13,000- \\
15,000\end{array}$ & 8,200 \\
\hline & \begin{tabular}{|l} 
Knee \\
Replacement
\end{tabular} & 24,454 & 5,000 & $\begin{array}{c}11,000- \\
17,000\end{array}$ & $\begin{array}{c}9,600- \\
13,000\end{array}$ & $\begin{array}{l}5,000- \\
12,500\end{array}$ \\
\hline \multirow[t]{2}{*}{$\begin{array}{l}\text { Spine and } \\
\text { Neurology }\end{array}$} & \begin{tabular}{|l} 
Spinal Fusion \\
Surgery
\end{tabular} & 32,500 & $\begin{array}{c}5,500- \\
8,000\end{array}$ & $\begin{array}{l}7,000- \\
10,500\end{array}$ & $\begin{array}{c}7,200- \\
10,500\end{array}$ & 5,900 \\
\hline & $\begin{array}{l}\text { Total Disc } \\
\text { Replacement }\end{array}$ & 71,200 & $\begin{array}{l}9,500- \\
11,500\end{array}$ & $\begin{array}{c}11,400- \\
19,600\end{array}$ & $\begin{array}{c}32,500- \\
48,000\end{array}$ & $\begin{array}{c}4,900- \\
6,600\end{array}$ \\
\hline \multirow[t]{3}{*}{ Dental } & Crown & 2,000 & $120-180$ & $\begin{array}{c}490- \\
550\end{array}$ & $\begin{array}{c}300- \\
500\end{array}$ & $\begin{array}{c}\text { Upon } \\
\text { request }\end{array}$ \\
\hline & $\begin{array}{l}\text { Dental } \\
\text { Implant }\end{array}$ & 5,465 & $\begin{array}{l}700- \\
1,500\end{array}$ & 2,600 & $\begin{array}{c}1,000- \\
3,000\end{array}$ & $\begin{array}{c}\text { Upon } \\
\text { request }\end{array}$ \\
\hline & $\begin{array}{l}\text { Teeth } \\
\text { whitening } \\
\text { (laser) }\end{array}$ & 2,300 & $\begin{array}{l}\text { Upon } \\
\text { request }\end{array}$ & $\begin{array}{c}235- \\
490\end{array}$ & $\begin{array}{l}\text { Upon } \\
\text { request }\end{array}$ & $\begin{array}{l}\text { Upon } \\
\text { request }\end{array}$ \\
\hline
\end{tabular}

Source: our elaboration. The data was compiled by medical tourism providers and online brokers.

* Source: allmedicaltourism.com database. The averages depend on price differences (from lower to higher) for the same procedures among different countries. 
sinergie Vol. 33, N. 97, 2015

Nowadays Thailand, India, and Mexico are the most important international hubs, not only for medical surgeries, but for cosmetic tourism as well. As Kopson (2010) reported, customers mainly move from the U.S., Canada, Britain and other European countries, since most cosmetic surgeries are not covered by medical insurance in the West countries and are therefore very expensive ${ }^{3}$.

Even if it is not our aim to focus on Italian Medical Tourism and existing differences between the U.S. and European healthcare systems, we underline the impact that travel and accommodation costs may have on Italian patients who look for treatment in India, Thailand or Singapore. Not surprisingly, Eastern Europe mainly appeals to Western Europeans and Italians due to its convenient location and much shorter airplane flights. Generally speaking, Eastern Europe offers cheap and reliable medical, dental and cosmetic surgeries, with Hungary, the Czech Republic, Poland, but also Croatia and Malta as the most popular selections by the Italian Portal for Medical Tourism.

However, lower costs are not the only driver for Medical Tourism: patients often travel abroad to avoid the long waiting times for procedures in their own countries (Hadi, 2009). In fact, waiting times vary among countries. In 2010, a high number of patients in Canada, Sweden, Norway, the United Kingdom and Australia reported waiting four months or more for elective surgery (Table 2).

Tab. 2: Waiting time of 4 months or more for elective surgery

\begin{tabular}{|l|c|c|c|c|}
\hline Country & \multicolumn{4}{|c|}{ Percentage of patients who waited more than four months } \\
\hline & $\mathbf{2 0 0 1 - 0 2}$ & $\mathbf{2 0 0 5}$ & $\mathbf{2 0 0 7}$ & $\mathbf{2 0 1 0}$ \\
\hline Canada & 27 & 33 & 27 & 25 \\
\hline Sweden & & & & 22 \\
\hline Norway & & & & 21 \\
\hline United Kingdom & 38 & 41 & 30 & 21 \\
\hline Australia & 23 & 19 & 18 & 18 \\
\hline New Zealand & 26 & 20 & 13 & 8 \\
\hline France & & & & 7 \\
\hline Switzerland & & & & 7 \\
\hline United States & 5 & 8 & 8 & 7 \\
\hline Netherlands & & & 7 & 5 \\
\hline Germany & & 6 & 5 & 0 \\
\hline
\end{tabular}

Source: OECD 2011

Excessive waiting times for non-emergency surgery often lead to stress, anxiety or pain (Sanmartin et al., 2004). Therefore many patients, mainly Canadian, travel to India, Thailand, Malaysia, or Philippines, where they can get treated almost immediately (Hadi, 2009).

3 The selected destinations by the Italian Portal for Medical Tourism are Costa Rica, Croatia, the Czech Republic, Hungary and Thailand for both female and male cosmetic surgery (as regards male cosmetic treatment on the other hand, Romania has been selected for hair transplant). Source: Italian Portal for Medical Tourism. 
The presence of legal or moral restrictions also impels patients to explore alternative countries in order to undergo the procedures they are looking for (such as surrogacy or organ transplant). The development of Reproductive Tourism, Medical Transplant Tourism, and even Death Tourism poses important legal and ethical issues in this sense.

\section{Avoiding "the rules": from "Reproductive" to "Death Tourism"}

Reproductive Tourism consists in "the travelling by candidate service recipients from one institution, jurisdiction or country where treatment is not available to another institution, jurisdiction or country where they can obtain the kind of medically assisted reproduction they desire" (Pennings, 2002 , p. 337). It refers to a practice in which people travel across national borders, in order to access reproductive technologies and services such as In Vitro Fertilization (IVF), gamete (sperm and egg) donation, sex selection, surrogacy, and embryonic diagnosis (Martin, 2009).

Legislation comes into play at almost every stage from when fertility treatment first takes place to how long frozen embryos may be stored following a successful treatment. For example, many countries like Turkey, China and Indonesia, will only permit IVF treatment for married couples, and New Zealand insists on a stable nuclear family to raise the child. By contrast, more liberal countries allow IVF for single people and homosexual couples.

Reproductive Tourism is not restricted to the U.S. or Australia, since the same phenomenon occurs in Europe, where patients from France, Germany or Italy ${ }^{4}$ travel to Belgium to undergo treatments that are not available at home, like, for example, IVF with oocyte or sperm donation (Pennings, 2002) and fertilization treatments for homosexuals, lesbians, or singles (not allowed in Italy, France and Germany). In stark contrast to Germany, Spain, and Czech Republic's restrictive rules are the European destinations selected by the Italian Portal for Medical Tourism for fertility treatments, but Cyprus, Russia, Ukraine, Greece, Turkey, India and Thailand also belong to the main selected destinations that provide reproductive outsourcing, since surrogacy and surrogate mothers are legal in those countries ${ }^{5}$.

As has been demonstrated by the Observatory on Reproductive Tourism (2012), 4,000 Italian couples went abroad for fertility treatments in 2011, 2,000 looked for gamete donors abroad and 32 Italian couples travelled to East European countries (mainly Russia and Ukraine), where surrogacy is allowed.

The same driver also leads Transplant Tourism. Currently, the World Health Organization estimates that of the 660,000 people in the world who require any form of transplant, $10 \%$ receive one every year. Of these, $10 \%$ receive their transplant through commercial Transplant Tourism.

4 In Italy in vitro fertilization treatments have been limited for a long time due to restrictions on gamete donations. These restrictions were declared unconstitutional in April 2014 so donor sperms and eggs are now also allowed in Italy (Italian Constitutional Court, April 2014).

5 Source: Health-tourism.com; discovermedicaltourism.com.
Rossella Canestrino Pierpaolo Magliocca Claudio Nigro

Drivers and implications

of medical tourism:

a neo-institutional 


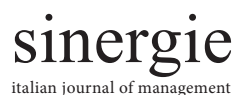
Vol. 33, N. 97, 2015

The European Union tried to boost organ donations by introducing a Europe-wide donor card, and has formed a regulatory body to standardize the quality and safety of transplantation in an effort to reduce commercial transplants. The People's Republic of China, which performs more transplants per year than any other country except the USA, has recently introduced tougher restrictions and penalties for commercial transplantation (Watts, 2007).

As a consequence, Iran is one of the few countries where selling organs is legal (Ghods and Savaj, 2006). In spite of this, the trade of organs for transplantation is still practiced in many underdeveloped countries (Turner, 2007; 2008; Cohen, 2013).

Pakistan is one of the "largest host centers for transplant tourism" in the world, with over 2,000 organs sold per year, about two thirds of which go to foreigners (primarily from the Middle East, South Asia, Europe, and North America). All the sellers are very poor and in debt. In Bangladesh an increase in organ trade has also been registered .

Finally, Death Tourism refers to terminally ill patients who travel to countries where assisted suicide ${ }^{6}$ or euthanasia ${ }^{7}$ are legal. Unsurprisingly, Death Tourism poses a deep ethical debate because the individual request for euthanasia and assisted suicide is complex in origin.

In the United States, euthanasia is prohibited in all 50 states under homicide laws. However, assisted suicide is legal in the states of Oregon, Washington, and Montana. Several approaches to euthanasia and assisted suicide are emerging in Europe. Due to strict international laws on euthanasia and assisted suicide, cases have begun to increase in countries with more liberal laws like Switzerland, the Netherlands, and Belgium.

Assisted suicide has been allowed in Switzerland since 1942. Swiss law tolerates assisted suicide when patients commit the act themselves and helpers have no vested interest in their death; active euthanasia, on the other hand, remains illegal ${ }^{8}$.

The Netherlands and Belgium are the only other countries where laws permit euthanasia or assisted suicide.

As the data show, there were 4,360 patients with an explicit intention of hastening death in 2010. Among that, 310 ended their life without any explicit request, 192 requested assisted suicide, and 3,859 asked for euthanasia9.

Belgium has legalized euthanasia since 2002 (Cohen et al., 2012) and it has become the first country to allow euthanasia for terminally sick children.

According to the conveyed picture, the main drivers of Medical Tourism seem to belong to the differences, in norms and values, that

6 A case where a doctor intentionally helps a person commit suicide by providing drugs for self-administration at that person's voluntary and competent request (Materstvedt, et al., 2003).

7 A case where a doctor intentionally kills a person by the administrating drugs at that person's voluntary and competent request (Materstvedt, et al., 2003).

8 Article 115 of the Swiss penal code considers assisted suicide a crime if and only if the motive is self-interest. On the contrary, it condones assisted suicide for altruistic reasons (Hurst and Mauron, 2003).

9 Statline Netherland (2010), Annual Report, www.cbs.nl 
characterize different countries. This entails that Medical Tourism develops by means of the existing gap between the Normative Institutional Frameworks and Symbolic Institutional Frameworks at a global level. This is the reason why the adoption of a neo-institutional approach allows us to innovatively interpret Medical Tourism, by opening it up to a novel understanding of the phenomenon.

In the following section a new perspective for interpreting Medical Tourism is shown. Starting from the original neo-institutional approach, as described within the literature, an extended model is proposed in order to involve the Institutional Frameworks and the Symbolic Frameworks of both domestic and host countries.

\section{Toward a new perspective: Medical Tourism within the Neo- Institutional Framework}

The idea that environmental forces affect organizational behavior is not new. The mainstream literature, in both managerial and organizational studies, recognizes that individual behavior depends on feedback from the environment, as well as on the interpretation of these inputs at an individual level.

What is really innovative here, in our opinion, is the emphasis on the dynamic re-shaping of the traditional concept of environment (more specified in the concept of organizational field), thanks to the uninterrupted interplay between action and institutionalization (Mastroberardino and Nigro, 2009; Mastroberardino et al., 2013a).

According to neo-institutionalism, key suppliers, resources and consumers, regulatory agencies, and other organizations that produce similar services and products belong to an Organizational Field, which is considered as a "recognized area of institutional life" (DiMaggio and Powell, 1983), founded by the aggregation and relations among organizations.

The Organizational Field does not refer to any geographical area: it is populated by organizations that are geographically dispersed and by competitive and cooperative interactions among them. As opposed to the concept of industry, the Organizational Field ${ }^{10}$ also involves normative and cultural relationships (Mastroberardino et al., 2013b).

In the early period of its development, the Organizational Field is characterized by a high degree of variety since different organizational forms are located within it. But over time, such variety has decreased and the Organizational Field has been institutionalized because of organizations' convergence toward models that are recognized as legitimate and with which new entrants must comply (Mastroberardino et al., 2013a). An Organizational Field that has a high degree of institutionalization develops forces that lead to homogeneity among the actors. The way according to which neo-institutionalism explains this process of homogenization is

10 The concept of Organizational Field refers to a community of organizations that share a common system of meanings. Within a field, actors interact with each other more frequently and more intensively than they do with actors outside of the field (Scott, 1998, p. 83)
Rossella Canestrino Pierpaolo Magliocca Claudio Nigro

Drivers and implications

of medical tourism: a neo-institution perspective 
sinergie Vol. 33, N. 97, 2015 called "isomorphism" (DiMaggio and Powell, 1983; Mastroberardino et al., 2013b; Nigro et al., 2015).

Figure 1 below shows the Organizational Field and its relationship with markets and institutions. As may be noted, the Organizational Field is animated by Institutional Entrepreneurs who interact with Markets and affect institutions through Institutional Work.

Fig. 1: The neo-institutional framework

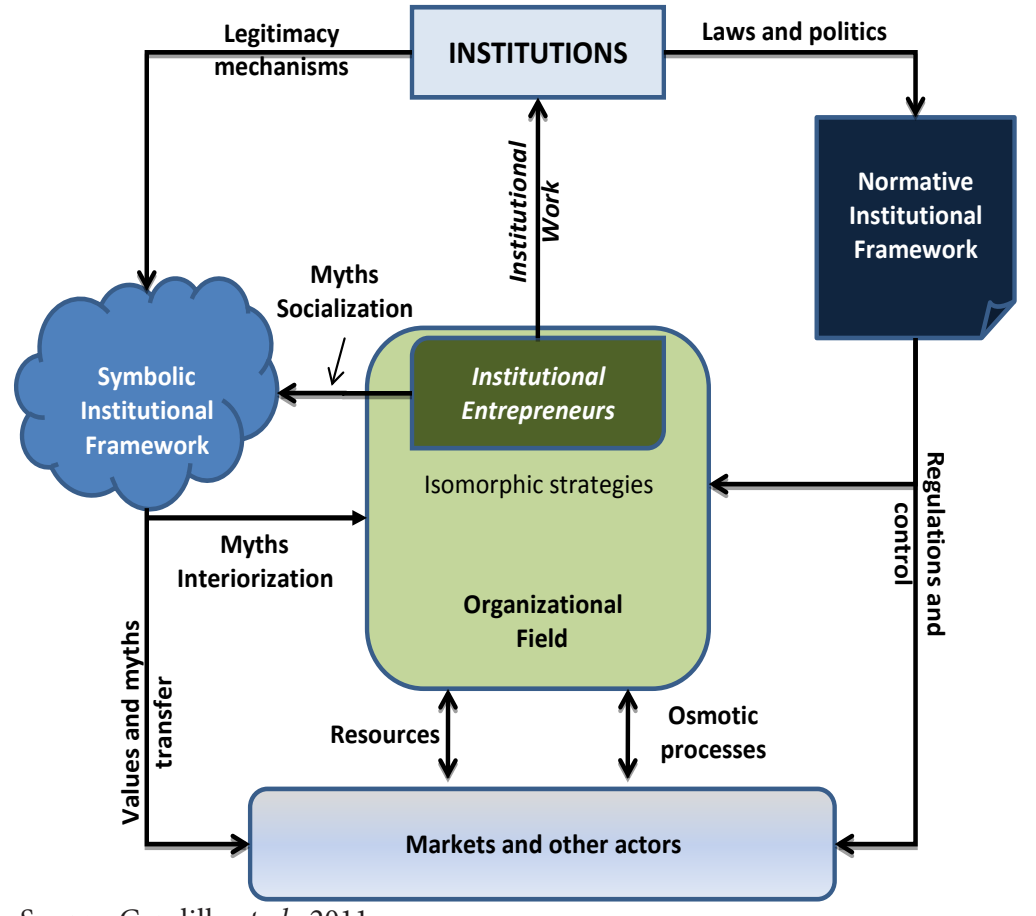

Source: Carolillo et al., 2011

Institutional Entrepreneurs are able to break with existing rules and practices by institutionalizing the alternative rules, practices or logics that they are championing. Strategies must therefore embed the change within a given Organizational Field, where different actors have invested in, are committed to, and take advantage of existing structural arrangements. It is not surprising, therefore, that Institutional Entrepreneurship manages a deep political process (Clemens and Cook, 1999; Greenwood and Suddaby, 2006). To be successful, then, entrepreneurial efforts must gain legitimacy, an undertaking that is more difficult as increasingly social groups with heterogeneous interests are involved in the process (Lounsbury and Glynn, 2001; Aldrich and Fiol, 1994).

The dynamic interaction between Institutional Entrepreneurs and Institutions gives rise:

1. on one hand, to a Normative Institutional Framework - new laws and norms according to which both Markets and Organizational Fields have to conform, even "pro tempore"; 
2. to a Symbolic Institutional Framework, on the other hand that absorbs, socializes, and transfers myths and values to the market in order to provide the background for social legitimacy (Carolillo et al., 2011).

As shown in figure 1, the Normative Institutional Framework and Rossella Canestrino Claudio Nigro Drivers and implications of medical tourism: a neo-institutional the Symbolic Institutional Framework affect the Organizational Field by establishing both the laws and moral principles according to which people have to adapt (laws and norms) or tend to behave (moral principles). In essence, actors and firms' behavior will be influenced by the prevailing rules and norms of their own Organizational Field, as well as by the culture, values, ideas and beliefs that are embedded in the social environment within which they are located. As Meyer and Rowan (1977) pointed out, the success or failure of an organization and its capacity to survive will no longer depend upon the effectiveness and efficiency of its performance, but rather on its adherence to ethical norms, rules, prescriptions and institutionalized knowledge. In choosing between alternative actions, subjects select those that conform most to institutionalized "standards" of conduct, regardless of their convenience (DiMaggio and Powell, 1983).

We do not propose that individuals are not autonomous agents, but we support the idea that they move within rules and symbolic patterns in order to gain legitimacy. In doing this, Institutional Entrepreneurs continuously modify the original standards by widening their own "space of actions" (Nigro et al., 2011; Mastroberardino et al., 2013a).

According to the above considerations, new implications may arise from the application of the presented theoretical framework to Medical Tourism. However, in its original formulation, the neo-institutional framework is highly embedded in the national context. An extension of the model is therefore required to fit with the global dimension of Medical Tourism, as demonstrated in the following section.

\section{When norms and symbols cross national borders}

As we noted in the previous sections, patients travel from home countries to host ones in search of looking for health care, mainly for cost-related reasons, time saving and availability of care that is illegal or un-ethical at "home". The players - key suppliers, brokers, resource and product consumers, agencies, etc. - seem to belong to the same Global Organizational Field. But since there are no mandatory Institutional or Symbolic Institutional Frameworks on a worldwide level, the latter maintain a national dimension.

Without neglecting the possibility that some international norms may control "key fields" in more than one country, laws and politics are nationally embedded: as a result, different Normative Institutional Frameworks may arise around the world. For this reason surrogate motherhood is illegal in Italy but allowed in Russia and Ukraine; euthanasia is only legal in the Netherlands and Belgium and patients coming from everywhere travel to Iran for an organ transplant (Ghods and Savaj, 2006).

Similarly, the Symbolic Institutional Framework is built upon the institutionalization of values and beliefs and their verbal manifestations - i.e. 
sinergie Vol. 33, N. 97, 2015 myths. In this sense, the Symbolic Institutional Framework mainly refers to the set of driving-rules and core beliefs that develop within a given society (which means culture), and affect what is considered right or wrong over time (Robertson 2002, Stajkovic and Luthans, 2001). Since no universal culture really exists, even under the pressure of globalization, different values and beliefs lead to different Symbolic Institutional Frameworks.

According to these considerations, different Normative Institutional Frameworks and Symbolic Institutional Frameworks may arise at a global level, referring, respectively, to domestic and host country Institutions.

Figure 2 shows an extended Situationist framework that may be used to interpret Medical Tourism.

With reference to Medical Tourism, the Organizational Field also acquires a global dimension: by moving in a global arena, Institutional Entrepreneurs interrelate with the Institutions of both domestic and foreign countries; they co-produce the Institutional Framework, i.e. the laws and rules that will control the market. In spite of the global dimension of the Organizational Field, the Institutional Framework maintains its local dimension, so rules and laws control Medical Tourism flows and procedures differently. Our considerations find support in the lack of internationally uniform norms aiming at governing Medical Tourism in different countries.

Fig. 2: The Situationist Framework of Medical Tourism

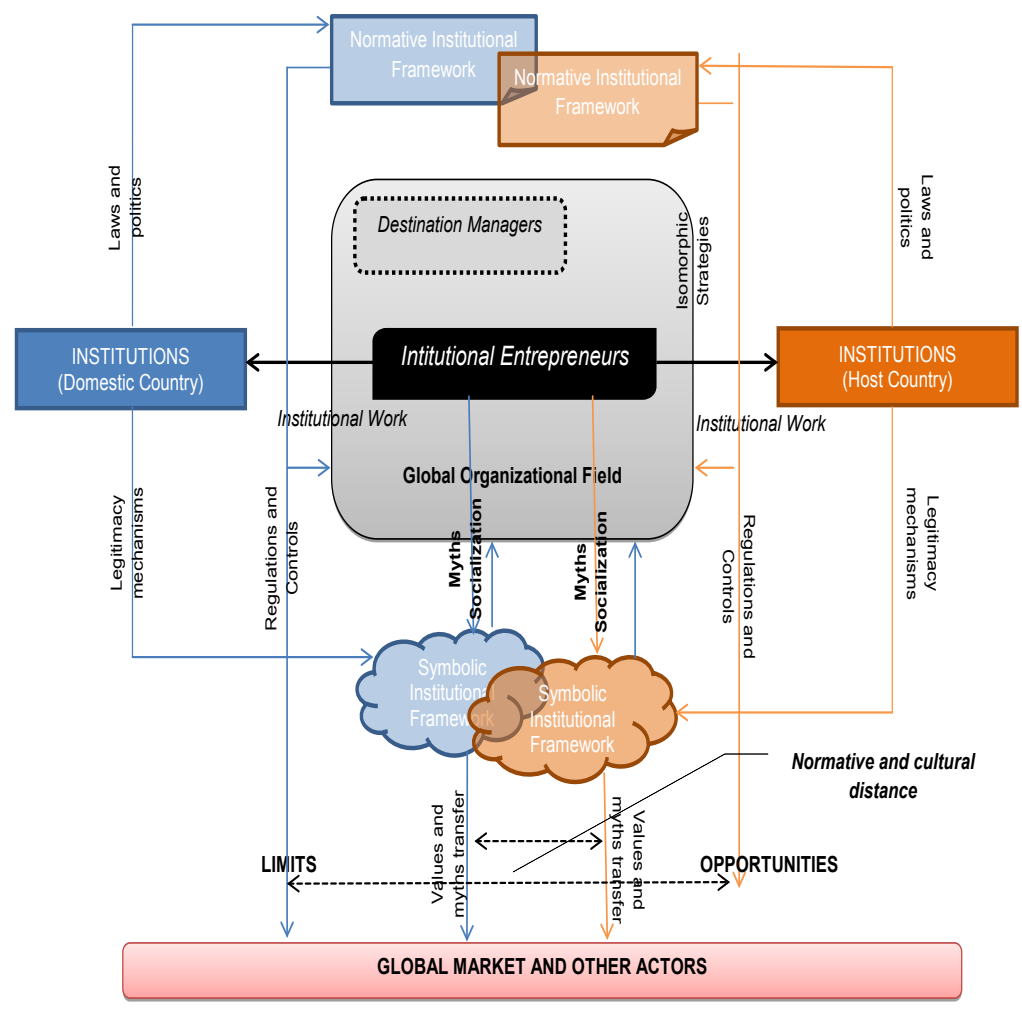

Source: our elaboration 
Sometimes, the Normative Institutional Frameworks overlap, which means that a given practice or procedure is allowed - or not - in both domestic and foreign countries and that it is similarly ruled. When Normative Institutional Frameworks significantly differ, however, a normative "gap" could be established with negative consequences for patients engaging in procedures that are not allowed in their home countries. This is the case, for example, of Reproductive Tourism: Italian law prohibits surrogacy while this practice is allowed in many other countries like Russia or Ukraine. As consequence, Italian patients go abroad for surrogacy, but when they come back, they run the risk to be jailed up to two years, even if the procedure is allowed in the host country (Source: rule 40/2004).

However, from an entrepreneurial point of view, the differences between, and among, Normative Institutional Frameworks at a global level are not negative at all. On the contrary, when rules and norms differ new opportunities arise for all the actors involved in the Medical Tourism flow: international brokers, insurance agencies, destination managers, national and foreign governments, as well as travelling patients. Without the mentioned differences among National Institutional Frameworks, Medical Tourism would only be driven by differences in cost among countries and its convenience for patients would greatly diminish.

Institutions and Institutional Entrepreneurs also play an important role in shaping the Symbolic Institutional Framework through legitimacy mechanisms and myths socialization. But while laws and politics are mainly nationally defined, values and beliefs can differ within the same country because of the emergence of sub-cultures. Similarly, certain values may overcome national borders in order to embrace similar cultural groups.

As a consequence, both legitimacy mechanisms and myths socialization become more and more complex when different cultures cross, since diversity in values and beliefs leads to the establishment of different moral standards (Donaldson and Dunfee, 1994; Canestrino, 2007).

But, what may happen when domestic and host country symbolic frameworks do not overlap?

Every time patients go abroad for treatment that are considered ethically "wrong" in their home countries, they are looking for legitimacy in the host country, since the practices they need may be morally accepted abroad, but not at home. When those same patients come back home, they often have to face moral judgment and, at least, social blame. As a consequence, patients going abroad usually request to remain anonymous in order not to 'face moral judgment when they come back home. As a result, intermediaries, brokers and destination managers very often engage all of their efforts to assure their clients' privacy (Source: ilportaledelturismomedico.com).

Even when a given practice is allowed at a normative level, it may be morally refused, thus affecting individuals' moral intimacy. This is the reason why, for example, even if it is a legal practice, euthanasia is differently accepted at a social level in Belgium ${ }^{11}$. Cohen et al. (2012) presented empirical evidence of differences in the acceptance of euthanasia by two

11 Obviously, in the case of euthanasia, we refer to the patients' family or friends, who come back home after they have assisted and supported the patient's experience abroad. 
sinergie Vol. 33, N. 97, 2015

Belgian cultural groups: Flemish and Walloon. In contrast to the Flemish's behaviour, the Walloon had a more negative attitude in performing euthanasia. The authors suggested that the influence of a euthanasia law on a particular society and the extent to which legal safeguards are followed are affected by culture and by societal symbolic meanings.

In such situations, Institutional Entrepreneurs may not be able to foster changes in the Normative Institutional Framework because of the over-embeddedness of the Symbolic Framework. In particular, referring to Medical Tourism, some examples are provided by the total rejection of some procedures, like surrogacy, assisted suicide, or trans-gender surgery, in countries where religion or even traditions lead to strong moral judgment. Unsurprisingly, we cannot wait for rapid changes in the Italian' Normative Institutional Framework, because of the relevance that Catholicism has for the social acceptance and moral legitimacy of some medical practices.

As we noted above, the emergence of differences among Normative Institutional Frameworks, as well as among Symbolic Institutional Frameworks is the main driver for the development of Medical Tourism on a global level.

\section{Discussion and conclusions}

In spite of its rapid diffusion, Medical Tourism is a topic that is still little investigated within the field of management studies. The lack of resources about it may depend on the difficulty of defining the phenomenon, as well as on the ethic controversies arising by its diffusion in many emerging countries, like Thailand, Singapore, or Malaysia. The existing overlapping between the two different industries - health and tourism - makes the analysis even more complex, with reference to both the drivers and the consequences of Medical Tourism at a global level.

Accordingly, we aimed at providing a new and valuable theoretical contribution for the understanding of Medical Tourism. In doing so, we adopted a Situationist perspective in order to take into account both the normative and cultural influences on patients' choices to go abroad for health care and therefore on the emergence of the phenomenon.

The most important difference between the "traditional" Situationist framework (as explained in section 5) and our enlarged model is the global dimension of the Organizational Field within which Medical Tourism develops, since it has never been used to investigate a global phenomenon until now. Without neglecting the importance of cost drivers in fostering the phenomenon, we therefore underline how both the Institutional Normative Frameworks and the Symbolic Institutional Frameworks of domestic and host countries shape the background for the emergence of Medical Tourism's global growth. Every time Institutional Normative Frameworks or Symbolic Institutional Frameworks differ from one country to another, patients look abroad for health solutions that are not available or morally accepted in their home countries. 
From a business perspective, the underlined gaps are also responsible for the emergence of business opportunities in a global market. In particular, we supported the idea that the higher the differences between and among Institutional and Symbolic Frameworks at global level, the higher the business opportunities abroad: if Normative Institutional Frameworks, as well Symbolic Institutional Frameworks, did not differ, there would be no actor capable of taking advantage of the development of Medical Tourism. It would mean that, in such a situation, Medical Tourism would be not developed at all.

The adoption of the Situationist framework, especially in its wider perspective, allows both researchers and practitioners to better understand the drivers that underlie the emergence and the diffusion of Medical Tourism.

In spite of this, however, other aspects need to be investigated, mainly in reference to the consequences and the impact that the examined phenomenon may have at a societal level. Despite the new business opportunities that may arise thanks to Medical Tourism for the involved actors - destination' managers, international brokers, insurance agencies, hospitals, hotels, and so on - the international migration of patients may be responsible for the social un-sustainability of Medical Tourism. Not surprisingly, the latter has been criticized by many authors.

Firstly, in many destinations, the "dream of growth" must confront the challenges of social inequality and un-sustainability. A "dual healthcare system" seems to arise here, with highly specialized private clinics devoted to foreigners and wealthy domestic patients and a local and public healthcare system that is often unsuited to serve the local and poor population even for basic needs.

Secondly, as Adams et al. (2013) noted, the provision of medical care to foreign patients may encourage a shift in the allocation of resources such as public finance or human resources, from the public to the private sector.

Both the emergence of a "dual healthcare system" in many destinations, and the ethical questions related to the "morality" of extreme procedures that are not undertaken in the patients' domestic countries may, therefore, damage the cornerstones of the social sustainability of Medical Tourism.

The supporters of social sustainability usually alert against the risks and challenges of Medical Tourism for global healthcare equity, pointing out the necessity for a global "governance" capable of routinely monitoring its growth, developing rules that acceptable to all stakeholders and maximizing the benefits of this approach for the health and the well-being of all populations. More specifically, Medical Tourism, as described in the previous sections, may affect fundamental human rights, such as those to life and health, by limiting or allowing individuals' the freedom to access health care.

In according with our observations, many questions about Medical Tourism and the ethical issues following its rapid development need to be answered: Is Medical Tourism sustainable? How long will countries' differences in costs, laws and norms support Medical Tourism? What about Reproductive, Transplant and Death Tourism? Can we assure the social sustainability of Medical Tourism considering emerging opportunities for both developed and underdeveloped countries?

These final unanswered questions encourage future investigations that open up to new and interesting research directions. This could be 
sinergie Vol. 33, N. 97, 2015 accomplished by matching the various literary fields that are connected, on one hand, to Medical Tourism, and on the other, to social sustainability, which could enable us to expand our knowledge about the topic.

\section{References}

ADAMS K., SNYDER J., CROOKS V.A., JOHNSTON R. (2013), "Promoting social responsibility amongst health care users: medical tourists' perspectives on an information sheet regarding ethical concerns in medical tourism", Philosophy, Ethics, and Humanities in Medicine, vol. 8, n. 19, pp. 1-10.

ALDRICH H.E., FIOL M.C. (1994), "Fools Rush In? The Institutional Context of Industry Creation", Academy of Management Review, vol. 19, n. 4, pp. 645-670.

BLOUIN C., CHOPRA M., VAN DER HOEVEN R. (2009), “Trade and social determinants of health", Lancet, vol. 373, n. 9662, pp. 502-507.

CALABRESE G., BERTIPAGLIA M., MORRIELLO D. (2011), "Azione etica e istituzionalizzazione morale nella visione situazionista dell'impresa. La strategia di Banca Popolare Etica", Sinergie, n. 86, pp. 113-132.

CANESTRINO R. (2007), "Business Ethics and Firms' internationalization processes. The impact of culture on "ethical gap", IACCM Conference "Cross-cultural Life of Social Values", 18-19 May, Rotterdam.

CAROLILlO G., MASTROBERARDINO P., NIGRO C. (2011), "The 2007 financial crisis: strategic actors and processes of construction of a concrete system", Journal of Management and Governance, vol. 17, n. 2, pp. 453-489.

CLEMENS E.S., COOK J.M. (1999), "Politics and institutionalism: explaining durability and change", Annual Review of Sociology, vol. 25, pp. 441-466.

COHEN G. (2013), "Transplant Tourism: The Ethics and Regulation of International Markets for Organs", The Journal of Law, Medicine and Ethics, vol. 41, n. 1, pp. 269-285.

COHEN J., WASEMAEL Y.V., SMETS T., BILSEN J., DELIENS L. (2012), "Cultural differences affecting euthanasia practice in Belgium: One law but different attitudes and practices in Flanders and Wallonia", Social Science and Medicine, vol. 75, n. 5, pp. 845-853.

CONNELL J. (2006), "Medical tourism: Sea, sun, sand and ... surgery”, Tourism Management, vol. 27, n. 6, pp. 1093-1100.

CONNELL J. (2013), “Contemporary medical tourism: Conceptualisation, culture and commodification", Tourism Management, vol. 34, n. 1, pp. 1-13.

CORMANY D., BALOGLU S. (2011), "Medical travel facilitator websites: An exploratory study of web page contents and services offered to the prospective medical tourist", Tourism Management, vol. 32, n. 4, pp. 709716.

DIMAGGIO P.J., POWELL W.W. (1983), "Institutional Isomorphism: The Iron Case”, American Sociological Review, vol. 48, n. 4, pp. 147-160.

DONALDSON T., DUNFEE T.W. (1994), “Towards a unified conception of business ethics: Integrative social contracts theory", Academy of Management Review, vol. 19, n. 2, pp. 252-84. 
GHODS A.J., SAVAJ S. (2006), "Iranian Model of Paid and Regulated PivingUnrelated Kidney Donation”, American Society of Nephrology, vol. 1, n. 6, pp. 1136-1145.

GREENWOOD R., SUDDABY R. (2006), "Institutional Entrepreneurship in mature Rossella Canestrino Pierpaolo Magliocca Claudio Nigro Drivers and implications of medical tourism: a neo-institutional fields. The Big Five accounting firms", Academy of Management Journal, vol. 49 , n. 1, pp. 27-48

HADI A. (2009), "Globalization, medical tourism and health equity", Symposium on Implications of Medical Tourism for Canadian Health and Health Policy, 13 November, Ottawa.

HEUNG V.C.S., KUCUKUSTA D., SONG H. (2010), "A Conceptual Model of Medical Tourism: Implication for Future Research", Journal of Travel and Tourism Marketing, vol. 27, n. 3, pp. 236-251.

HIGGINBOTHAM G. (2011), "Assisted-suicide tourism: is it tourism?", Turismos: An International Multidisciplinary Journal of Tourism, vol. 6, n. 2, pp. 177185.

HOPKINS L., LABONTĖ R., RUNNELS V., PACKER C. (2010), “Medical Tourism Today: what is the state of existing Knowledge?", Journal of Public Health Policy, vol. 31, n. 2, pp. 185-198.

HURST S.A., MAURON A., (2003), "Assisted suicide and euthanasia in Switzerland: allowing a role for nonphysicians", BMJ, vol. 326, n. 7383, pp. 271-273.

INHORN M.C. (2011), "Diasporic Dreaming: return reproductive tourism to the Middle East", Reproductive Biomedicine Online, vol. 23 n. 5, pp. 582-591.

JAGYASI P. (2008), "Defining medical tourism. Another approach", Medical Tourism Magazine, n. 6, pp. 9-11, available at http://www.medicaltourismmag.com/ wp-content/uploads/2008/08/issue-6.pdf.

JOHNSTON R., CROOKS V., SNYDER J., KINGSBURY P. (2010), "What is known about the effects of medical tourism in destination and departure countries? A scoping review", International Journal for Equity in Health, vol. 9, n. 1, pp. 24.

KOPSON M.S. (2010), "Medical tourism: implications for providers and plans", Journal of Health and Life Sciences Law, vol. 3, n. 2, pp. 147-165.

LAWS E. (1996), "Health tourism: A business opportunity approach" in Clift S. and S.J. page (Eds.) Health and the International Tourist (pp. 199-214), Routledge: London and new York.

LOUNSBURY M., GLYNN M.A. (2001), "Cultural entrepreneurship: Stories, legitimacy, and the acquisition of resources", Strategic Management Journal, vol. 22, n. 6-7, pp. 545-564.

LUNT N., CARRERA P. (2010), "Medical tourism: assessing the evidence on treatment abroad", Maturitas, vol. 66, n. 1, pp. 27-32.

LUNT N., SMITH R., EXWORTHY M., GREEN S.T., HORSFALL D., MANNION R. (2012), "Medical Tourism: Treatments Market and Health System Implications. A scoping review", OECD, Directorate for Employment, Labour and Social Affairs. Available at: <http://www.oecd.org/els/healthsystems/48723982.pdf> [Accessed 25 August 2014].

MARTIN L. (2009), "Reproductive tourism in the age of globalization", Globalizations, vol. 6, n. 2, pp. 249-263.

MASTROBERARDINO P., NIGRO C. (a cura di) (2009), Le dinamiche di governance d’impresa. Cenni sullapproccio etnometodologico, ESI, Napoli. 


\section{sinergie} Vol. 33, N. 97, 2015

MASTROBERARDINO P., NIGRO C., CALABRESE G., PETRACCA M. (2013a), "Il processo innovativo nella prospettiva situazionista", Referred Conference Proceedings XXV Convegno annuale di Sinergie "L'innovazione per la competitività delle imprese”, Ancona 24-25 October, pp. 35-49.

MASTROBERARDINO P., IANNUZZI E., CORTESE F., MORRIELLO D. (2013b), "Processi isomorfici, innovazione e cambiamento", Referred Conference Proceedings XXV Convegno annuale di Sinergie Convegno annuale di Sinergie "L'innovazione per la competitività delle imprese", 2425 October, pp. 21-34.

MATERSTVEDT L.J., CLARK D., ELLERSHAW J., FORDE R., GRAVGAARD A.M., MÜLLER-BUSCH H.C., PORTA I SALES J., RAPIN C.H. (2003), "Euthanasia and physician-assisted suicide: a view from an EAPC Ethics Task Force”, Palliative Medicine, vol. 17, n. 2, pp. 97-101.

MEYER J.W., ROWAN B. (1977), "Institutional organizations: Formal structure as myth and ceremony", American Journal of Sociology, vol. 83, n. 2, pp. 340-363.

NIGRO C., IANNUZZI E., PETRACCA M. (2015), "Cultural Management between Isomorphism and Docoupling" Conference Proceeding, IFKAD, June 2015, Bari, Italy.

NIGRO C., IANNUZZI E., CAROLILlO G. (2011), "Comunicazione e strutturazione di un quadro istituzionale. Riflessioni sulla recente crisi del sistema finanziario", Sinergie, n. 89, pp. 109-130.

PENNINGS G. (2002), "Reproductive tourism as moral pluralism in motion", Journal of Medical Ethics, vol. 28, n. 6, pp. 337-341.

POCOCK N.S., PHUA K.H. (2011), "Medical tourism and policy implications for health systems: a conceptual framework from a comparative study of Thailand, Singapore and Malaysia", Globalization and Health, vol. 7, n. 1, pp. 1-12.

POLLARD K. (2011), “The medical tourism numbers game” Part 2. www.imtj. com/articles/2011/blog-medical-toursim-nmbers-game-part-two-401.

ROBERTSON D.C. (2002), "Business Ethics across Cultures" in Gannon M.J., Newman K.L., The Handbook of cross-cultural Management, Blackwell Business, Oxford.

SANMARTIN C., GENDRON F., BERTHELOT J., MURPHY K. (2004), "Access to Health Care Services in Canada, 2003", Catalogue No. 82-575-XIE, Statistics Canada, Ottawa.

SCOTT R.W. (1998), Organizations: Rational natural and open systems, Upper Saddle River, Prentice Hall, Englewood Cliffs, NJ.

SMITH M., PUCZKO L. (2009), Health and Wellness Tourism, ButterworthHeinemann, Routledge, London.

STAJKOVIC A.D., LUTHANS F. (2001), "Differential effects of incentive motivators on work performance", Academy of Management Journal, vol. 44 , n. 3, pp. $580-590$.

TURNER L. (2007), "First World Health Care at Third World Prices: Globalization, Bioethics and Medical Tourism” BioSocieties vol. 2, n. 3, pp. 303-325.

TURNER L. (2008), "Cross-border dental care: 'dental tourism' and patient mobility", British Dental Journal, vol. 204, n. 10, May, pp. 553-554.

WATTS J. (2007), "China introduces new rules to deter human organ trade", Lancet, vol. 369, n. 9577, pp. 1917-11918. 


\section{Academic or professional position and contacts}

\section{Rossella Canestrino}

Assistant Professor in Business Management

DISAQ - "Parthenope" University of Naples - Italy

e-mail: rossella.canestrino@uniparthenope.it

\section{Pierpaolo Magliocca}

Assistant Professor in Business Management

University of Foggia - Italy

e-mail: pierpaolo.magliocca@unifg.it

\section{Claudio Nigro}

Full Professor in Business Management

University of Foggia - Italy

e-mail: claudio.nigro@unifg.it
Rossella Canestrino Pierpaolo Magliocca

Claudio Nigro

Drivers and implications

of medical tourism:

a neo-institutional

perspective

sinergie italian journal of management

ISSN 0393-5108 DOI $10.7433 / \mathrm{s} 97.2015 .17$ pp. $271-289$

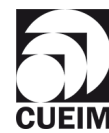

